\title{
Cytological investigation of intrathoracic lymph nodes in carcinoma of the lung
}

\author{
CYR IL S I MEしEK
}

From the Pulmonary Diseases Department, Palacký University, Olomouc, Czechoslovakia

One of the sites for metastases from lung cancer and the one most frequently affected is the intrathoracic nodes (Miyaji, Kitamura, Senoo, Oda, and Murata, 1955 ; Senoo, 1956; Nohl, 1956; Šmeček, Simečková, and Krejči, 1959). We record a method of perbronchial puncture of intrathoracic nodes, performed during bronchoscopic examination (Swierenga and Versteegh, 1956; Simeček, 1956 ; Simeček, 1963) that makes cytological examination possible and, frequently, histological investigation as well (Schiessle, 1962). We have endeavoured to evaluate the significance of this method for establishing the extent of involvement of mediastinal nodes.

\section{METHOD}

The intrathoracic nodes were punctured and investigated cytologically in all patients in whom a presumptive diagnosis of lung cancer had been made and who were submitted to bronchoscopic examination in our department. Investigation of intrathoracic nodes was omitted only in patients who already had obvious distant metastases in other organs, and in those in whom diagnosis had been verified morphologically by some other method. No patients were included in this series who had already reached an advanced stage of the disease with involvement of the principal bronchi or direct infiltration of the tracheal wall. Patients were also excluded from this series when the diagnosis of lung cancer could not be unequivocally confirmed even by further investigation.

The nodes at the bifurcation of the trachea and at the hilum of the lung were punctured and aspirated as well as obviously enlarged nodes located elsewhere and visible on chest radiographs ; in fact those were usually the tracheobronchial nodes.

The technique of puncture of intrathoracic nodes with immediate cytological investigation has been described elsewhere in detail (Simeček, 1963). We use phase contrast for determining the success or failure of aspiration during bronchoscopy. All aspirates are evaluated after staining by the panoptic method of Pappenheim, or occasionally by fluorescence microscopy, as described by Bertalanffy (Bertalanffy, 1961 ; Šimeček, 1964).

\section{RESULTS}

Cytological investigation of intrathoracic nodes was performed in $\mathbf{4 1 8}$ patients who were suffering from lung cancer by a total of 613 punctures. Squamous-cell carcinoma was found to be present in 198 patients, small-cell carcinoma in 121, adenocarcinoma in 41 , and large-cell carcinoma in 15 ; the histological type of cancer was not determined in 43 persons.

The bifurcation nodes were investigated in 264 patients, the hilar nodes in 265 , and other intrathoracic nodes in 94 patients. Positive evidence of malignant cells was recorded in $33 \%$ of the patients whose bifurcation nodes were investigated, in $62 \%$ after investigation of hilar nodes, and in $71.2 \%$ with punctures of intrathoracic nodes located elsewhere. Out of the total of 613 punctures, $50.9 \%$ provided evidence of malignant cells in $58.1 \%$ of all persons investigated.

There were differences in the positive results according to the site of the primary growth and according to the histological type of cancer (see Figure).

Whereas positive results in cases of squamouscell carcinoma amounted to $48.5 \%$ and in adenocarcinoma to $53.7 \%$, the number of positive results in anaplastic forms of cancer was distinctly higher, $89.3 \%$ in small-cell and $80 \%$ in large-cell carcinoma. Positive results obtained in cancer of undetermined type numbered only $11 \cdot 6 \%$.

\section{DISCUSSION}

The development of metastases marks a fundamental change in the evolution of cancer of the lung and, particularly in the anaplastic forms of cancer, as a rule the end of expectations of lasting 


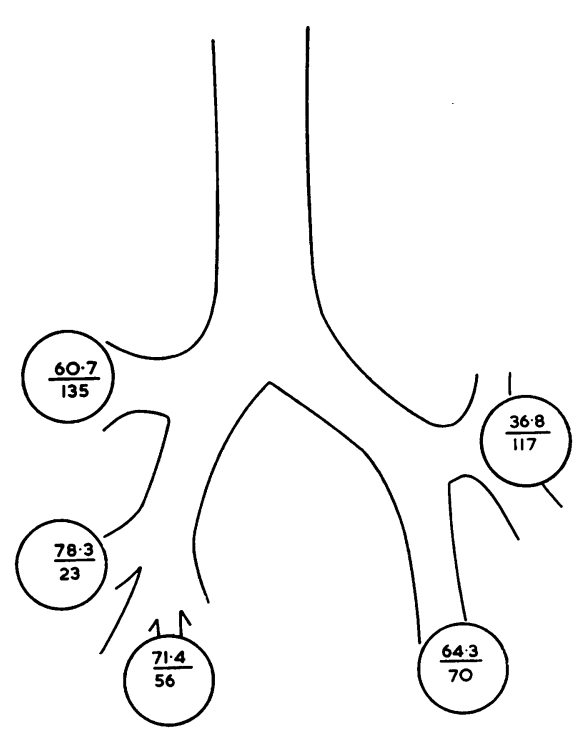

FIGURE. Schematic drawing showing differences in positive results of cytological investigation of intrathoracic nodes, according to the site of the primary carcinoma. The upper figure of the fraction denotes the percentage of positive results; the figure below shows the number of patients investigated whose carcinoma was situated in the respective pulmonary lobe.

recovery. The state of the intrathoracic nodes must therefore be considered to be of decisive significance from a prognostic viewpoint. Several methods are available for the diagnosis of lymph node metastases in lung cancer. If we omit biopsy of obviously enlarged peripheral nodes, then one of the best and, from the patient's angle, the least burdensome methods is the investigation of the prescalene nodes as described by Daniels (1949); but positive results are not often obtained in cancer of the lung (Higgins and Brownlee, 1959) and may only be expected during the more advanced stages of the disease.

Substantially more may be expected from the method introduced by Carlens (1959) and called mediastinoscopy. However, its field of access is limited to a small part of the mediastinum. A better image of the state of the mediastinal lymph nodes is provided by the technique of diagnostic pneumomediastinography. The radiographic image, however, cannot carry as much weight as morphological evidence of node involvement by malignancy. In addition, the nodes harbouring metastases need not always and immediately show enlargement, and such nodes escape attention if pneumomediastinography is used (Simeček and Holub, 1961).
Cytological investigation of material obtained by puncture of the intrathoracic nodes is considered to be a useful supplement of routine bronchoscopic examination in patients suspected to be suffering from cancer of the lung (Versteegh and Swierenga, 1963). Other authors present evidence on the frequent involvement of intrathoracic nodes by cancer of the lung, though there are differences in the results obtained, mainly according to the circumstances in which node metastases were discovered. Nohl (1956) found metastases of regional nodes in $75 \%$ of resection spzcimens of lung cancer, Ščukareva (1964) in only $52 \cdot 8 \%$. Both authors found lymph node metastases associated more frequently with anaplastic cancer than with squamous-cell cancer, as did other writers (Daumet, Daussy, Drouhard, and Mignot, 1963 ; Rienhoff, Talbert, and Wood, 1965), and we ourselves in necropsy material (Šimeček et al., 1959).

The results of cytological investigation of intrathoracic nodes in our series are comparable with the results presented by the writers referred to above. The number of metastases confirmed by cytological investigation of material aspirated by puncture of intrathoracic nodes, however, is lower than in necropsy material. This is easily understood. Similarly, the fact that metastases are more frequently demonstrated by investigation of resection specimens can also be explained. This difference provides an indication of the proportion of metastases that escape recognition by cytological investigation of intrathoracic nodes. The differences between the results of histological examination of resection specimens and our results of cytological investigation of material aspirated by lymph node puncture are slight.

Accordingly, we may conclude that cytological investigation of intrathoracic nodes represents a $ᄋ$ significant method for clinical diagnosis, providing useful evidence as to the extent of disease in patients with carcinoma of the lung. At the same time these differences reveal that cytological $\sigma$ investigation of intrathoracic nodes should be $\tilde{N}$ supplemented by further methods providing still $\underset{\omega}{N}$ more accurate evidence concerning node involvement. In our view, one of the most useful in this respect is diagnostic pneumomediastinography $\stackrel{\mathbb{D}}{\overparen{D}}$

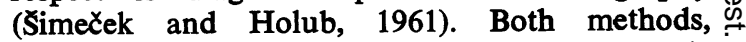
pneumomediastinography and lymph node 0 puncture, are performed by us in the course of a single bronchoscopic examination. The supplementary insufflation of gas into the mediastinum $\mathbb{D}$ carries no additional burden for the patient and should not be omitted in any patient who is a 
possible candidate for surgery. The combination of both methods provides sufficient information concerning the state of the intrathoracic nodes and facilitates correct decisions on further therapeutic procedure.

\section{SUMMARY}

Cytological investigation of material obtained by puncture of intrathoracic lymph nodes in 418 patients who were suffering from cancer of the lung disclosed the presence of lymph node metastases in $58.1 \%$ of investigated cases. Their incidence differed according to the site of the primary growth and to its histological type. Results obtained show that cytological investigation of intrathoracic nodes is valuable in that it provides-particularly in combination with diagnostic pneumomediastinography - information concerning the extent of disease in patients with lung cancer.

\section{REFERENCES}

Bertalanffy, F. D. (1961). Zur Cytodiagnostik des Krebses: Fluoreszenzmikroskopie nach Acridinorange-Färbung. Triangel (De.), 5, 152 .

Carlens, E. (1959). Mediastinoscopy: A method for inspection and tissue biopsy in the superior mediastinum. Dis. Chest, 36, 343.
Daniels, A. C. (1949). A method of biopsy useful in diagnosing certain intrathoracic diseases. Ibid., 16, 360.

Daumet, P., Daussy, M., Drouhard, P., and Mignot, J. (1963). Métastases ganglionnaires intra-thoraciques des cancers bronchopulmonaires. J. franc. Méd. Chir. thor., 17, 543.

Higgins, G. A., and Brownlee, W. E. (1959). Prescalene fat pad biopsy. J. thorac. cardiovasc. Surg., 38, 402.

Miyaji, T. Kitamura, H., Senoo, T., Oda, T., and Murata, Y. (1955). Morphological study of 406 cases of bronchogenic carcinoma in Japan. Gann, 46, 523.

Nohl, H. C. (1956). An investigation into the lymphatic and vascular spread of carcinoma of the bronchus. Thorax, 11, 172.

Rienhoff, W. F., Talbert, J. L., and Wood, S., Jr. (1965). Bronchogenic carcinoma: a study of cases treated at Johns Hopkins Hospital from 1933 to 1958. Ann. Surg., 161, 674.

Schiessle, W. (1962). La ponction transbronchique et transtrachéale des adónopathies p'́ri-trachéo-bronchiques. $J$. franc. $\mathrm{Med}$. Chir. thor., 16, 551 .

Šcukareva, N. K. (1964). Osobennosti rosta i metastazirovanija raka legkogo $v$ regionarnyje limfatičcskije uzly. (In Russian with English summary.) The peculiarities of lung cancer growth and of its metastasization into regional lymph nodes. Vopr. Onkol., 10, no. 9, p. 8 .

Senoo, T. (1956). Metastasis of 400 necropsy cases of bronchogenic carcinoma: statistical and morphological studies. Med.J. Osaka Univ., 7, 515.

Šmecek, C. (1956). Perbronchiální a pertracheální diagnostické punkce. (In Czech with English summary.) Transbronchial and transtracheal diagnostic punctures. Acta Univ. Palack. Olomucensis, 11, 199.

— (1963). Cytologická vyšetřeni v pneumologii. SZdN, Prague.

- (1964). Fluorescenční mikroskopie $v$ cytologické diagnostice. Rozhl. Tuberk., 24, 688.

- and Holub, E. (1961). Pneumomediastinography in carcinoma of the lung. Thorax, 16, 65.

_ Simecková, B., and Krejú, J. (1959). Rozdíly v obraze rakoviny prudusek podle histologického typu. (In Czech, with English summary.) Differences in the clinical picture of lung carcinoma according to the histological type. Vnitrrit Lik., 5, 594.

Swierenga, J., and Versteegh, R. M. (1956). Transbronchiale punctiebiopsie. Ned. Geneesk, 100, 2364.

Versteegh, R. M., and Swierenga, J. (1963). Bronchoscopic evaluation of the operability of pulmonary carcinoma. Acta oto-laryng., 56, 603 . 